\title{
Participatory Communication based on Digital Platforms for Communities in Indonesia
}

\author{
Hamzah Turmudi \\ UIN Sunan Gunung Djati Bandung, Indonesia \\ email:
}

\begin{abstract}
The emergence of participatory communication models is an alternative to conventional development communication practices and theories that are one-way. With a democratic, participatory model, civil society can be further involved in social change and support programs that are carried out by stakeholders. This article simply explains the application of participatorybased development communication in Indonesia and its implementation to digital media through examples of the presence of the Qlue Application. Armed with a literature study, this article tries to re-raise the discourse of the importance of the contribution of the study of communication science and the adoption of digital technology for development.
\end{abstract}

Keywords: Development Communication, Participatory Communication, Digital Media

\section{A. Introduction}

In the perspective of Wilbur Schramm (1964), development can improve the level of community life, provided the community is proactive or involved in the activity. For the community to participate, the city must be informed so that it can play a role in the development communication process. Simply stated, communication of development itself can be understood as the process of disseminating information carried out by an individual or group actors to a broader audience to change attitudes, opinions, and behavior (Effendy, 1993).

Therefore, in the perspective of development and social change, communicating is more than just sending messages, persuading, or providing media. The classic communication formula in the communication concept of "Who says What through Which channel to Whom with What effect?" Harold Laswell was considered no longer relevant to increase the concrete contribution of communication science. Likewise, the diffusion theory of innovation introduced by Everett M. Rogers in 1964. This model is considered to still be in a vertical perspective or one-way Laswell-style communication because the success of communication for development is related to the active involvement of personal contact as supporting the penetration of information from the mass media ( Servaes, 2008). 
The criticism conveyed by Jan Servaes towards the model is the neglect of the actors of communication for the development of the complexity and characteristics of the community and related cultures. When social change accelerators also do not recognize the features of the communities they target, development communication may become an ineffective or futile process (Servaes, 2008). When there is still doubt about the benefits of communication for development, this is where development communication requires a new formula or strategy.

One alternative to increase the effectiveness of development communication (development communication) is a participatory communication model. According to Servaes (2008), the participatory communication model emphasizes the importance of the cultural identity of local communities and democracy and participation at all levels, ranging from international, national, regional, and individual. Thanks to participatory communication packaged in an appropriate education system, according to Pradip Thomas, poverty can be eliminated. Its applied form can be with consistent growth in agriculture, education, politics, health, to the economy. Some of the methods offered by Thomas (in Servaes, 2008) include recruiting journalists in rural areas to cover unique news and stories, and more information must be received by people outside the relevant scope, investing in participatory communication projects initiated by local communities, also involves the local community in developing a communication strategy in an area.

Carpentier, Lie, and Servaes (2008) provide another example in the application of participatory democracy, namely when it alludes to the contribution of people who consciously and intentionally group or community. A community group can present community media for a variety of interests, from performing new aspects and paradigms that tend to be independent to become antithetical to mainstream media or to complete them, to show the existence and identity of the community, to serve the community members themselves. As an alternative to mainstream media, community media with a smaller scope have a chance to have a high proximity value for groups of people who inhabit a particular area or identity. However, community media also have challenges that cannot be underestimated, namely marginalized by mainstream media who want to conduct a monopoly.

In another article, Rheinghold (2008) supports Thomas's argument by encouraging teachers to support the enthusiasm of adolescents in using participatory media to increase the involvement of civil society in the application of this communication model. The participatory media referred to here include blogs, social networks, wikis, podcasts, virtual communities, and videoblogs (vlogs). Nevertheless, this effort has the potential to be hindered by several factors and needs to be solved first to facilitate the use of participatory media in the teaching curriculum, such as lack of learning resources, technical support, and training for the instructors themselves. 
The Preparedness of the community - or the younger generation in the context of Rheinghold's (2008) study above - in using participatory media is closely related to the enthusiasm of individuals in the community to contribute to the environment and the people around them. It is not uncommon for the public voice to be sent using participatory media to be an answer to the government's attitude or statement, which is considered not in favor of the public. This culture is broadly different from printing culture before the 21st century because most media functions are still diffusive. The era of the internet and digital as now is seen as the right moment to allow people to aspire and be listened to, although before that effort is pursued, it is necessary to hold a briefing on the use of participatory wise media.

\section{B. Literature Review}

\section{Rejection of Modernism and the Development of Participatory Communication}

Before the development, communication experts went to participatory in looking at the approach to solving a problem - especially a matter of society and its social change - there was an old model, which was nuanced of modernism. Distributive model of participatory communication approach, closely related to local cultural identity, and collective is the rejection of the failure of top-down modernization, tend to be authoritarian, and ignorant of opponents or communication targets influenced by Daniel Lerner's thinking in the 1950s and 1960s ( Servaes \& Malikhao, 2005). This kind of character also rejects modernization actors, namely developed countries that still want to have control over developing and newly independent countries in Asia and Africa after World War II, which coincided with the collapse of Nazis and fascism.

Historically, modernization evolved from a system of control that was mirrored by the United States to developing and emerging countries, namely economic growth. When the physical occupation was no longer relevant in the 20th century, the US took full advantage of its capital and potential: more sophisticated technology, rows of companies from various sectors ready to play at the international level, and an established political and economic system. They also managed to make most third world countries tempted by this paradigm, thus upholding the perception that the economy must grow so that they can be called progress.

In the end, there was a dependency that was taught between the superpowers and developing countries. At a time when large countries needed a variety of potentials owned by third world countries, the colonialism of information received by developing country people was also considered normal because at that time the information system was still chaotic, infrastructure was not ready, and there were a variety of other problems that covered, including political nuances. The 
modernization theory, which was popular in the 1960s to 1970s, was closely related to the concept of infusion of mass communication. With the dissemination of information through the media, third world countries can accelerate their movement more quickly from traditionalism to modern society (Shanahan, 2009).

Even though it has been widely recognized in many countries, it still needs to be held to hold that modernization is a benchmark that is inaugurated by the West. The modernization perspective is centered on the idea of evolution. This means that development is seen as one way forward or professional and cannot be returned and in harmony with the upholding of a nation's identity.

This movement toward modernization is not without consequences. Traditionalism, superstition, or other local genius works are considered inferior, out of date, irrelevant, until the barrier that must be removed. In a way, many local and distinctive values are left behind by developing country people to reach a point equivalent to developed countries, for example, by adopting more sophisticated technology or adapting practices that are prevalent in developed countries to their local culture and environment, namely modern society.

Modernization is now starting to get a variety of disputes. One example is what has been done by the United Nations (UN) since 2012, which is making the world's happiest country report. The World Happiness Report, as the study was dubbed, is a commitment from the United Nations to correct the perception of many countries that people's prosperity cannot be prioritized by economic progress.

The UN, which also encourages a shift from top-down or vertical communication to two-way or horizontal communication to facilitate social change, can be called positioning itself opposite the concept of modernization. Helen Clark, Head of the UN Development Program (UNDP) 2009-2017, in one of her speeches mentioned that the most critical effort in advancing people in a country and stabilizing their growth is to make them happy. The state should not submit to the "tyranny of GDP" (Clark, 2017).

In another article, Servaes (2017) also recognizes that there is a shift from the study of communication to social development and change from modernization to the dependency approach. This paradigm shift was taken as an increased understanding of the complexity between the relations of globalization and localization. As a result, the conceptualization change from the end of the 20th century to the beginning of the 21st century re-raised local or regional values as an indicator of human development assessment. The Gross National Product (GNP) is indeed still calculated as the era of the modernization paradigm. Again, it does not define the absolute progress or failure of a country and defines human existence in the area. 
Servaes (2017) then concludes that more and more people are assessing the position of communication and culture as very important as a solution to today's problems. Also, he emphasized the importance of Communication for Sustainable Social Change (CSSC) as an essential area of study. The targeted polemic was able to be resolved by the CSSC, among others: village development, natural resource management, and the environment, and poverty.

\section{Gotong Royong, Indonesian Distinctive Development Communication}

Indonesian society is no stranger to the concept of cooperation, such as this participatory, just a different name. The idea was explained by Soekarno, the first President of the Republic of Indonesia, in his famous speech at the BPUPKI session on June 1, 1945, as the core of Pancasila, namely Ekasila or cooperation. By stating that the principle of this country was cooperation, Soekarno implied that this country did not belong to any particular group or group, let alone personal. Cooperation, furthermore, is an awareness to work hand in hand and join hands for the common good (Dewantara, 2017).

Quoting Bowen (1986), who examined the concept in the country, he found that cooperation has become an essential element in the cultural and political system of society. By carrying out aid, civilians have the right to empower each other because every member of the community or group who wants to work together is asked to voice every idea and aspiration for the common good.

Bowen (1986) was even amazed by this concept, as he mentioned that cooperation reflects social relations in a society that is running well and in harmony. The phenomenon that does not forget to underline Bowen in his article is that collaboration is not oriented towards personal gain. An example is how a community group of farmers can help each other without asking for or giving payment.

\section{Participatory Media}

Participatory media are media that provide an opportunity for the audience to play an active role in the process of gathering, reporting, analyzing, and disseminating content. This type of communication is unique because it provides an opportunity for someone to communicate with many people and allows a two-way exchange of information between them. As a result, there was an interactive and collaborative information sharing activity among residents (Seth, 2008).

Rheigold (2008) classifies three general characteristics of participatory media. First, it is public-to-public (many-to-many), which allows anyone connected to the network to share and receive text, images, audio, video, software, data, and others from and to everyone else. Second, it is the participatory or active participation of many people, which ultimately makes the value and power of a media meaningful. While the latter is networked, allowing for more comprehensive, faster, and cheaper 
coordination of activities with the power of information and communication network infrastructure. In the digital age, forms of participatory media have become more and more diverse. Some of them are blogs, wikis, music-photo-video sharing, podcasts, and videoblogs.

\section{Research Methods}

This study uses a qualitative approach to the type of literature study research. Through the review of the literature, this research is oriented to look for theoretical references that are relevant to exist phenomena. This research is expected to be used as a necessary foundation for the analysis of problems or further more complex research.

\section{Results and Discussion}

To support participatory democracy, there is one method that is very applicable for increasing community involvement, namely utilizing a participatory media platform and accommodating internet-based public aspirations. This strategy has proven to be liked and attached to the younger generation. Data from the Pew Internet and American Life Project cited by Rheingold (2008), explains that in 2005 alone, young people using the internet in the United States had increased 24 percent compared to the previous four years. The majority, 87 percent, are netizens aged 12 to 17 years. They are noted not only as consumers of content on the internet but also as creators. Enthusiasm and high adoption of web publishing, social networking, online games, and digital video by young people almost all over the world take an interest in learning digital content production, and, especially, communication skills also increase.

In Indonesia alone, the penetration of internet users is also getting deeper. We Are Social (2019) writes that of the 268 million people in Indonesia, the people who have been connected to the internet have reached 150 million. While social media users via mobile devices amounted to 130 million, no doubt, with the increasing number of people here being connected to the internet and smartphones, this phenomenon can also support participation in information and communication technology-based.

One platform that can support these activities is Qlue (http://qlue.co.id). The mobile application-based startup that was founded by Rama Aditya tried to be a solution for the development of DKI Jakarta by accommodating reports, criticisms, and suggestions from the citizens of the capital of the environment, ranging from floods, congestion, roads or other public facilities that were damaged, criminal acts, fire, and so on. Not just reporting, citizen complaints that are equipped with photos, information, and the location of the reporter also sought direct action by government officials who have authority. Qlue itself was launched in December 2014 and is part of the Jakarta Smart City program. 


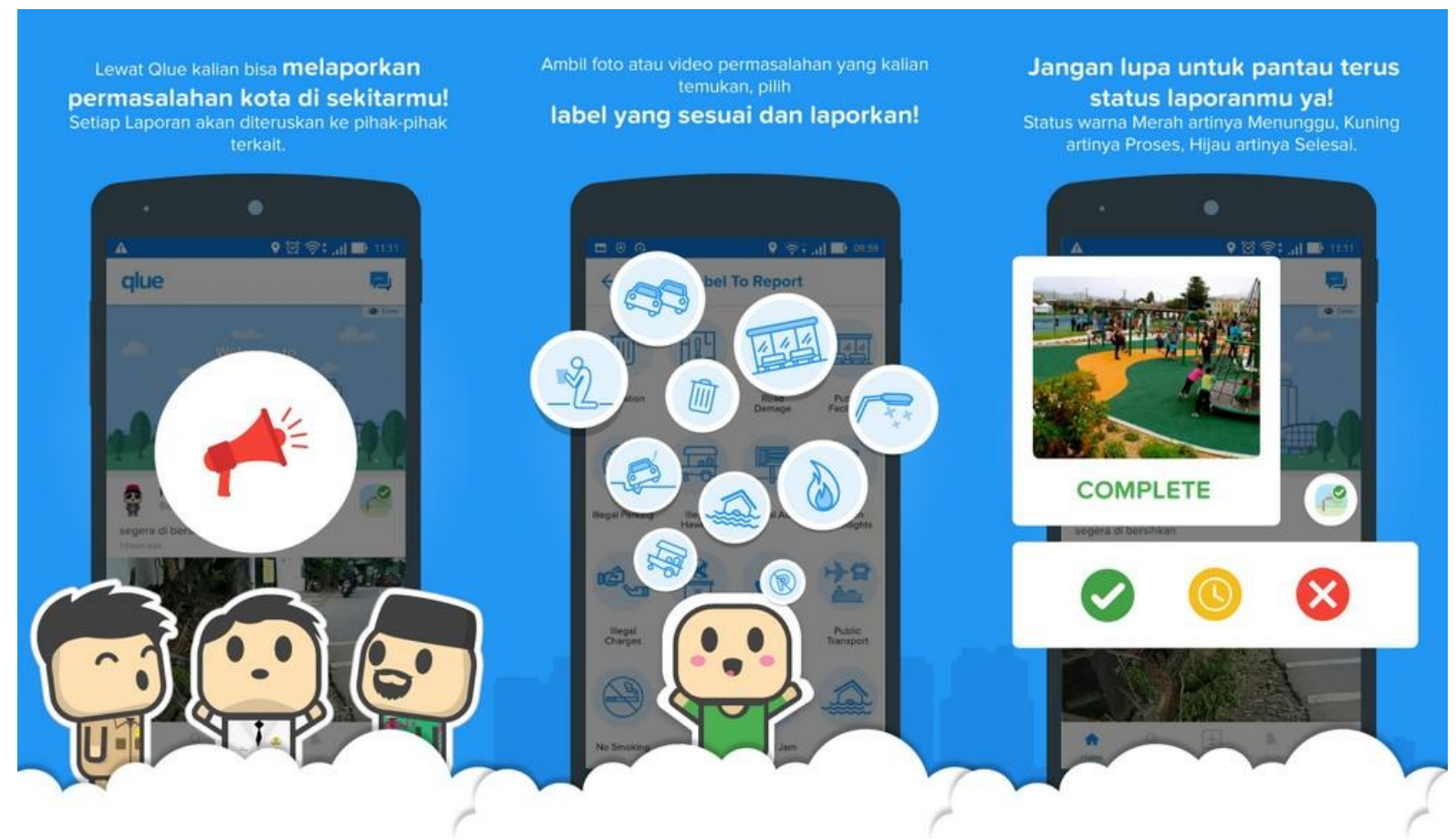

Figure 1: Illustration of how the Qlue application works. Source: play.google.com

This application can be downloaded and used for free in devices based on the Android and iOS operating systems. Before you can use it, people need to register first and complete the data, including the village of residence. Then, registered users can directly make various reports or complaints to the DKI Jakarta Provincial Government, such as garbage, floods, congestion, damaged roads, etc., through the round icon and select reports to the government from this application. the story can also be monitored progress to ensure that it has been followed up (SmartCity.Jakarta.go.id, 2015)

So far, Qlue has gained the trust of the people of Jakarta. One of the reasons is because the DKI Jakarta government has responded seriously to reports and complaints from the public, it is evident from the percentage of Qlue claims that have been followed up to 87 percent with an average rating of four stars.

Nevertheless, there was a decline in the report through Qlue when the Governor and Deputy Governor of DKI Jakarta Anies Baswedan and Sandiaga Uno took office in 2017. The reason was that residents thought the change of governor affected the follow-up of their report. However, the number of Qlue complaints has gradually increased in 2018 because claims continue to be followed up (Ramadan, 2019).

The concept carried by the platform that labels itself as a 'civic engagement app' is more or less applying the idea of participatory democracy articulated by UNESCO, namely access, participation, and self-management (Servaes, 1996). First, 
access refers to the use or availability of media for public services. With the presence of Qlue, anyone is free to voice their aspirations, as long as they install the Qlue app on their mobile devices. With this, the citizens' right to access to provide and receive information to the government has been facilitated.

Meanwhile, the aspect of participation highlights public involvement in a communication mechanism. Residents who have used Qlue are very likely to encourage the participation of other residents if they are satisfied with the response of the relevant agencies to their reports. Because attendance is very carefully related to listening activities. Quoting Servaes and Malikhao (2005, p.91), "People don't want to speak out not because they don't have something to talk about, but no one wants to listen to them." After the public has access and participates, they can achieve the highest participatory level, which is self-management. The presence of Qlue can be seen as an effort to foster further stages of the public, that is, having the power to influence the communication strategy regarding policies and plans.

When connecting the phenomena of cooperation in Indonesia that Bowen perpetuated more than 30 years ago, the authors argue that the presence of Qlue is merely repeating and supporting what has been done and sought by people in the real world. This phenomenon is a simple form of technological determinism, a theory put forward by Marshall McLuhan that underscores how technology can shape how individuals who use it in thinking and behaving. Because, before the citizens of Jakarta were connected with the government through Qlue, the community was already familiar with concepts such as cooperation and deliberation.

Even so, according to Wyatt (2008), the presence of Qlue reflects the descriptive characteristic of technological determinism, namely that technology has independently developed social strength in society. This is in line with the principle of participatory communication for social change, which sees society as the core of development. In a participatory communication perspective, growth means strengthening local communities as active actors.

\section{E. Conclusion}

The challenges of communication to make social change in society are very heavy. This is not only due to the dynamic and diverse nature of society in each region, but communication as a tool is also not fully ready. Judging from the scientific field, communication is classified as a young domain. Its development that only began after the Second World War and the majority still serves the administrative studies needed for the status quo makes this domain of science always on its way to find its independence and concrete contribution.

The lack of communication studies in this science more or less influences the bluntness of this scientific spur to contribute to development communication. The 
proof, Servaes (2013) to highlights how the scope of communication studies is still not comprehensive. He argued that in the interests of progress and social change, five-tiered communication strategies were needed, namely:

1. Behavior change communication (BCC), or behavioral communication in the short term which mostly includes studies of interpersonal communication;

2. Mass communication (MC), which includes mass media, community media, and information and communication technology (ICT);

3. Advocacy communication (AC), or advocacy communication that deals with interpersonal or mass communication;

4. Participatory communication and social mobilization (PC), involving studies and elements of interpersonal communication and community media;

5. Contact for structural and sustainable social change (CSSC), with complexity and a mixture of implementations as well as studies of interpersonal communication, participatory communication, and mass communication.

Unfortunately, the concentration of students and communication science researchers is considered to be unbalanced, especially when comparing the top three points with the bottom two spots. To encourage social progress, studies at the high three points are not enough. The determinants are said to lie in the last two elements, namely participatory communication (PC) and communication for structural and sustainable social change (CSSC) because both are more focused on long-term community change (Servaes, 2013).

The reason, as further elaborated by Servaes (2013), approaches that only aim to change the behavior or paradigm of the wider community, individuals, and communities on a small scale, as well as policymakers and stakeholders, have not had much influence. Collective action from various parties in the broader scope is needed to create consistent social change. Therefore, the contribution of communication science, especially for social progress, is arguably still very long.

This contribution is a shared responsibility of communication scientists and students. Specifically, for communication science scientists from Indonesia, it is necessary to individually examine the correlation and implementation of the concept of cooperation with participatory communication from a non-western perspective. With the idea of participatory democracy that is already familiar with Indonesian society and brought together with digital smart city technology, the authors believe the future of participatory democracy is big enough to have a good impact on Indonesian society if these potentials can be maximized. 


\section{References}

1. Bowen, J. (1986). On the Political Construction of Tradition: Gotong Royong in Indonesia. The Journal of Asian Studies, 45(3), 545-561. doi:10.2307/2056530

2. Carpentier, N., Lie, R., \& Servaes, J. (2008). Making Community Media Work: Community Media Identities and Their Articulation in an Antwerp Neighbourhood Development Project. In Servaes, J. (Ed.), Communication for Development and Social Change (pp. 347-373). Californa: SAGE Publications.

3. Clark, H. (2017). Helen Clark: Keynote Speech at the Global Dialogue for Happiness "Where is Happiness on the Global Agenda?". Retrieved from https://www.undp.org/content/undp/en/home/presscenter/speeches/2017/02/11/h elen-clark-keynote-speech-at-the-global-dialogue-for-happiness-where-ishappiness-on-the-global-agenda-.html.

4. Dewantara, A. W. (2017). Alangkah Hebatnya Negara Gotong Royong: Indonesia dalam Kacamata Soekarno. Yogyakarta: PT Kanisius.

5. Effendy, O. U. (1993). Ilmu, Teori, dan Filsafat Komunikasi. Bandung: Alumni.

6. Wyatt, S. (2008). Technological Determinism Is Dead; Long Live Technological Determinism. In Hackett, E., Amsterdamska, O., Lynch, M., Wajcman, J. (Eds.), The Handbook of Science and Technology Studies (3rd ed.). Cambridge: MIT Press.

7. Ramadhan, A. (2019, 29 Maret). Apa Kabar Aplikasi Qlue di Jakarta?. Kompas.com. Retrieved from https://megapolitan.kompas.com/read/2019/03/29/06555001/apa-kabar-aplikasiqlue-di-jakarta?page=all.

8. Rheingold, H. (2008). Using Participatory Media and Public Voice to Encourage Civic Engagement. In Bennett, W. L. (Ed.), Civic Life Online: Learning How Digital Media Can Engage Youth (pp. 97-118). Cambridge: The MIT Press.

9. Schramm, W. (1964). Mass Media and National Development: the role of information in developing countries. Stanford: Stanford University Press.

10. Servaes, J. (2008). Introduction. In Servaes, J. (Ed.), Communication for Development and Social Change. Californa: SAGE Publications.

11. Servaes, J. (2013). Future Challenges for Communication for Sustainable Development and Social Change. In Servaes, J. (Ed.), Sustainable Development and Green Communication: African and Asian Perspectives. Hampshire: Palgrave McMillan.

12. Servaes, J. (2017). Conclusion Are the SDGs "Sustainable"?. In Servaes, J. (Ed.), Sustainable Development Goals in the Asian Context. Singapura: Springer.

13. Servaes, J., \& Malikhao, P. (2005). Participatory communication: the new paradigm?. In Hemer, O., \& Tufte, T. (Eds.), Media \& Glocal Change: Rethinking Communication for Development (pp. 91-103). Buenos Aires: CLASCO.

14. Seth, A. (2008). Understanding Participatory Media Using Social Networks. Technical Report, University of Ontario. 
15. Shanahan, J. (2009). Broadcasting Theories. In Littlejohn, S., \& Foss, K. (Eds), Encyclopedia of Communication Theory (pp. 79-83). California: SAGE Publications.

16. Smartcity.Jakarta.go.id. (2015). Laporkan Kinerja Pemerintah Melalui Qlue. Retrieved from https://smartcity.jakarta.go.id/blog/34/laporkan-kinerjapemerintah-melalui-qlue.

17. We Are Social. (2019). Digital 2019 Indonesia. Retrieved from https://www.slideshare.net/DataReportal/digital-2019-indonesia-january-2019v01?ref=https://datareportal.com/reports/digital-2019-indonesia. 